\title{
IN-SERVICE TEACHERS' VIEWS ON DEVELOPING COMMUNICATIVE COMPETENCE AT PRIMARY LEVEL IN THE PROCESS OF TEFL IN SLOVAKIA
}

\author{
Klaudia Paulikova ${ }^{1}$
}

\begin{abstract}
Reaching communicative competence in a foreign language is one of the key objectives of the foreign language education policy of multiple European countries, including Slovakia. The unified concept of communicative competence provides learners with equal opportunities for mastering languages at their best and enables its development from the very beginning of learners' studies. In low proficiency levels (A1) in primary education, teachers play a crucial role in developing the communicative competence of their learners. Research in the field reveals that although teachers are aware of their great influence and importance in the development of communicative competence, they often do not provide sufficient circumstances for learners to reach it. A qualitative inquiry conducted with a number of in-practice English teachers working in Slovak primary schools presents the importance of having balanced development in all the components of communicative competence in TEFL, its implementation into the lessons of English, as well as an overall view of teachers' standpoints towards its development at the primary level. The results show the tendencies of teachers to concentrate more on certain (especially linguistic) elements of communicative competence, whereas other competences (mainly of pragmatic character) are often neglected.
\end{abstract}

UDC Classification: 81`27, DOI: https://doi.org/10.12955/pss.v2.235

Keywords: communicative competence, English, primary level, interview

\section{Introduction}

TEFL has gone through vast changes in the past several decades. A great variety of theories, approaches, and teaching methods have emerged, which led to the formation of an endless resource inventory, FLE, which can be made use of. The present demands of the global world society are setting high standards in what users of foreign languages should be capable of. We ought to be technically advanced, have excellent ICT skills, and be outstanding communicators. Due to these standards, many countries in the world are setting their philosophy on language policies in such a way that learners develop communicative competence in at least one or two foreign languages (Tandlichova, 2008). English, even though it is not the largest language by speakers and geographic spread, is the language of the 'global village' (Romaine, 2007). Even though curricular documents in their frameworks and guidelines for teaching portray the objectives of education without giving stepby-step instructions of how exactly teaching should be done (Harmer, 2012), reaching communicative competence is one of the most important objectives in them all.

The current study investigates the development of communicative competence from the viewpoint of in-service English teachers at the primary level. The theoretical overview provides information on what communicative competence is, how it is referred to at the primary level, and what role teachers have in its development. The main aim of the study is to find out how teachers understand the phenomenon and how frequently they include its elements into their teaching process. The findings and discussion portray the most prominent results and provide an insight into teachers' own views on communicative competence.

\section{Literature Review}

There have been numerous linguists and authors dealing with what communicative competence is. In modern FLE, it can be defined as "[...] the ability that allows learners to establish successful communication in a foreign language, in genuine contexts, and through everyday tasks found in real life. Being competent implies more than knowing the linguistic code; it also necessitates being able to negotiate meaning and to interact socially in the target language" (Gomez-Rodriguez, 2010, p. 330).

Thus, we should take into account five main components of communicative competence - linguistic competence, discourse competence, sociolinguistic competence, strategic competence, and functional competence. Linguistic competence should entail the knowledge of lexis, morphology, phonology, and syntax. Discourse competence should enable users to use language in various situations in discourse. Sociolinguistic competence should encompass both social and cultural contents and enable learners to use sociocultural rules and rules of discourse in communication with regards to register, dialects, nature of language, cultural differences, and functions of language effectively. Strategic competence

${ }^{1}$ Constantine the Philosopher University in Nitra, Slovakia (Department of Language Pedagogy and Intercultural Studies), kpaulikova@ukf.sk, ORCID: 0000-0001-7761-271 
should stand for verbal and non-verbal strategies for compensating errors, problem-solving, cognitive management in language use, and skills for negotiating messages. Functional competence, lastly, should entail acquiring skills in using the functional language of utterances in discourse, which include interpersonal exchanges, defining opinions, feelings, suasion, problems, and speech acts (Council of Europe, 2001).

TEFL at the primary level in Slovakia is associated with proficiency level A1. As these young learners are in the first two years of their foreign language studies, it is natural that the teaching process itself is required to be well adjusted to their needs. The Common European Framework of Reference for Languages (CEFR) marks communicative competence as vital to be incorporated into FLE from the very beginning of the teaching process(Council of Europe, 2001). Paulikova (2019) provides a document analysis revealing the individual components of communicative competence based on international and national reference documents and gives an overall description of their elements. According to these, communicative competence at the primary level should comprise three groups of competences - linguistic, sociolinguistic, and pragmatic, which are defined by seven subcompetences.

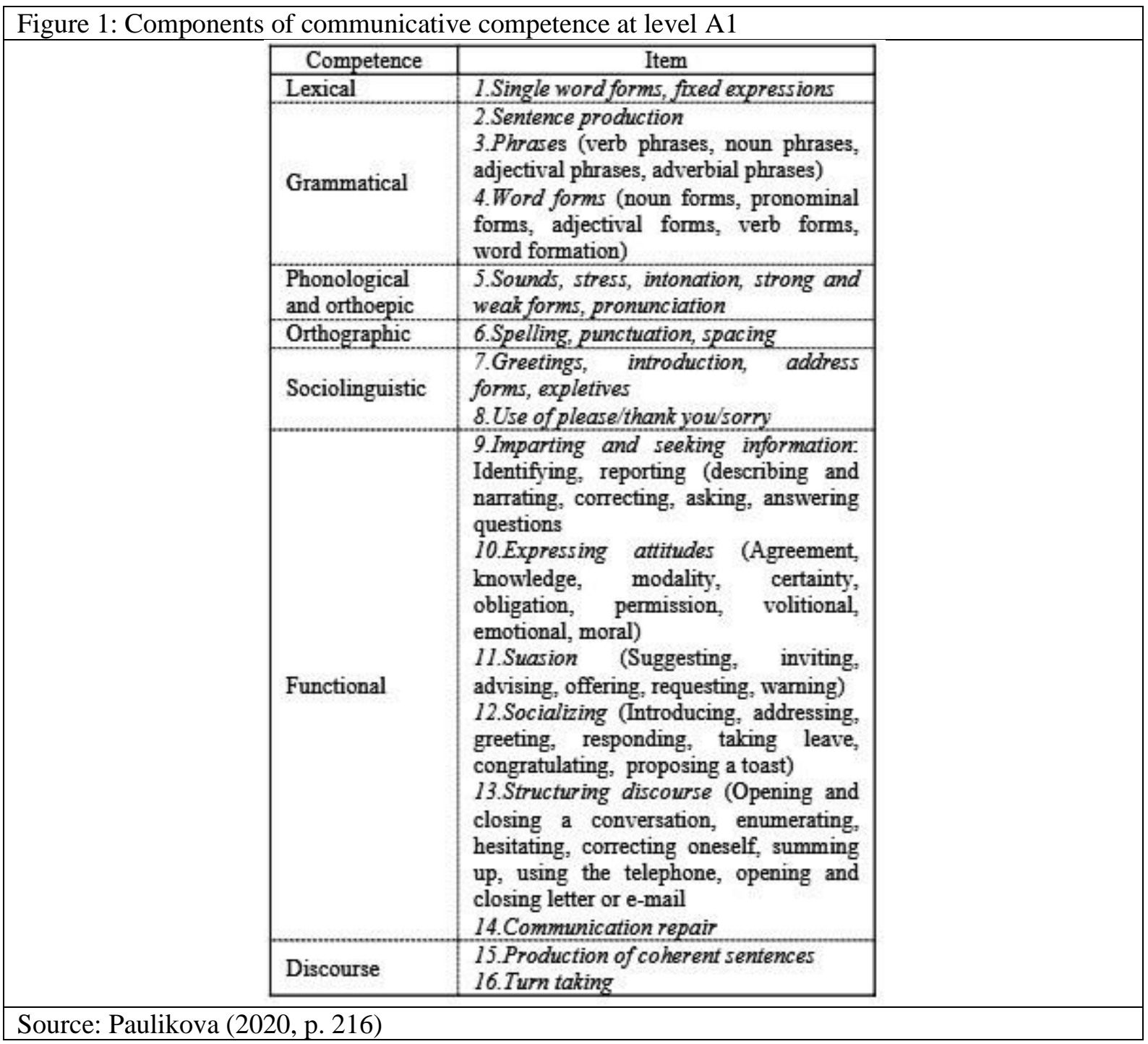

On the basis of these, learners at this stage of their studies should master the seven components of communicative competence in accordance with the requirements specified for level A1 in CEFR (Council of Europe, 2001; Trim, 2001). These requirements state that a successful user of language at level A1:

Can understand and use familiar everyday expressions and very basic phrases aimed at the satisfaction of needs of a concrete type. Can introduce him/herself and others and can ask and answer questions 
about personal details such as where he/she lives, people he/she knows, and things he/she has. Can interact in a simple way provided the other person talks slowly and clearly and is prepared to help (Council of Europe, 2001, p. 24).

Teachers themselves should be aware of being the most important factor in the teaching process (Kováčiková\&Gajdáčová-Veselá, 2016). According to several studies, teachers' quality was, in fact, found to be the leading factor that influences learners' achievements (King Rice, 2003). Savignon's (1972) experiment demonstrated that learners that engaged in more communicative teaching reached better results in overall language acquisition as opposed to learners provided with traditional teaching. Different studies, however, reveal that even though teachers play a crucial role in this process, rarely do they know how to deal with such teaching in reality. They find it difficult to define what communicative competence is, which leads to incomplete coverage of its components at lessons (Gonzales-Pelaes, 2008). Other studies show that teachers believe communicative competence refers only to speaking skills and it does not cover teaching grammar explicitly; therefore, they do not implement activities developing communicative competence into the teaching process (Weerawong, 2004; Wong, 2010). Straksiene (2011) found that lessons were dominated by reproductive methods (memorization, reading techniques, and the development of vocabulary), whereas little or no attention was paid to correct pronunciation and its elements. The ability to interact in conversations and social interaction was, though, found to be included in many cases. It is assumed that with enough background knowledge and well-structured and planned lessons, teachers can have a great impact on developing their learners' communicative competence successfully.

\section{Methodology}

This study was aimed at investigating the development of communicative competence from the viewpoint of in-service English teachers by a qualitative enquiry with some numerical aspects. The researcher was investigating two main aspects of communicative competence - how teachers understand it in general and how they relate to its components in the actual teaching process. Therefore, two research questions were formed:

- How do teachers of English understand communicative competence?

- Which aspects of communicative competence do, according to the teachers, prevail in the teaching process and which ones are rather neglected?

The study took place at different primary schools in Slovakia, where data about teachers' reflections on the investigated topic were collected. The investigated level of our study was the primary level. At this level, pupils start learning English as a compulsory foreign language generally at the 3rd grade of their studies. There are 3 lessons of English per week in Slovak schools and they last for 45 minutes each. The average number of pupils in a class is 25 , but for learning foreign languages, they are divided into two groups. English classes, therefore, have around 13 pupils per class. TEFL in Slovak primary schools is subject to the two main reference documents in the country - The National Curriculumand School Curriculum. The former is a binding document that specifies the general objectives of education as well as the key competences to which education should be aiming and is written in accordance with international reference documents. The latter is based on the National Curriculum; it does, however, take into account the specific conditions and needs of individual regions of the country. It is issued and published by school directors and must be in accordance with the objectives and principles defined by the National Curriculum(ŠPU, 2019). Naturally, all the reference documents, both national and international are designed in correspondence, and they aim at the development of communicative competence equally.

\section{Participants}

The participants of the study were selected via volunteer sampling. Altogether 15 in-service English teachers - 2 males and 13 females participated in the study. They came from different parts of Slovakia, from smaller villages to cities, but they all taught at different primary schools in the same region of southern Slovakia in the time of research. The teachers were aged between 28 and 56. The length of their teaching practice varied from 3 to 22 years. The longest English teaching practice was ten years. They were ensured that the data collection would be completed with no expectations, and the representation of the data would be done with complete integrity and precision without any biases. All the participants of the study participated voluntarily, with the opportunity to withdraw at any time. 
Their anonymity was ensured, as well as their privacy protected. Neither private information, nor the names of teachers or schools were published anywhere throughout the course of the study.

\section{Data Collection and analysis}

A semi-structured synchronous interview with open-ended questions was conducted in the beginning of 2020. Such interviewing allows the researchers to bring up new ideas based on what interviewees say (Edwards and Holland, 2013). Moreover, open-ended questions are flexible enough to let the interviewers elicit cooperation, seek deeper insight, or even clear misunderstandings. Thus, new and unexpected information can be collected (Cohen, Manion \& Morrison, 2007).

The interview was conducted with each of the participants individually. It comprised 14 questions and lasted for about 60 minutes. The recorded interviews were transcribed, and the transcriptions were analysed via coding and categorisation. The fundamental components of communicative competence served as the basis for our codes, but the analysis of transcriptions revealed some additional codes. The findings are therefore depicted according to the research questions and provide an overall overview of the received results.

\section{Findings and Discussion}

The teachers' general viewpoints on the teaching process itself were somewhat dissimilar in multiple aspects. The majority of them declared opting for creating a learner-friendly atmosphere in their classrooms by being democratic and liberal in their teaching strategy because they believed this maximizes the pupils' performance. None of them regarded themselves directly as an important, influential factor in the teaching process; they rather pointed to the importance of a good atmosphere and proper choice of study materials and techniques. Their concept of communicative competence and its importance within the teaching process was viewed, however, rather differently.

\begin{tabular}{|l|l|}
\hline \multicolumn{2}{|l|}{ Table 1: Teachers' views of TEFL in general } \\
\hline \multirow{2}{*}{$\begin{array}{l}\text { Important aspects } \\
\text { of teaching }\end{array}$} & $\begin{array}{l}\text { Pronunciation (12 teachers) } \\
\text { Lexical knowledge (11 teachers) } \\
\text { Grammatical structures (10 teachers) } \\
\text { Speaking (7 teachers) } \\
\text { Successful communication (3 teachers) }\end{array}$ \\
\cline { 2 - 3 } $\begin{array}{l}\text { Definition of } \\
\text { communicative } \\
\text { competence }\end{array}$ & $\begin{array}{l}\text { Ability to use language in different situations (7 teachers) } \\
\text { Ability to speak (5 teachers) } \\
\text { Knowledge of and ability to use grammatical rules (3 } \\
\text { teachers) }\end{array}$ \\
\hline \multirow{2}{*}{ Teaching objectives } & $\begin{array}{l}\text { Wellbeing of learners (11 teachers) } \\
\text { Effective results of the teaching process (11 teachers) } \\
\text { Fulfilling the teaching plan (4 teachers) }\end{array}$ \\
\hline Source: Author & \\
\hline
\end{tabular}

When talking about the most important aspects of teaching English, some of the teachers explained that it is not easy to define specific aspects, as mastering language complexly is the most important. Nevertheless, when pointing out what they taught was important, the respondents primarily regarded different components of linguistic competence as the key ones. Correct pronunciation was mentioned by most of them as they believed that without learning pronunciation well, pupils have very little chance of succeeding in communication. Lexical knowledge was regarded as key for gaining solid foundations of language for further studies. Grammatical structures were regarded as being engaged in the vast part of the teaching process, as they are included in most of the examinations and tests. The pragmatic aspect in terms of speaking was regarded as important only for half of the interviewed teachers, who claimed that involving a variety of communicative tasks helps pupils acquire realistic language ready to be used outside the classroom. Lastly, successful communication on a general scale was found to be important for only three teachers.

For the teaching objectives, we discovered that the wellbeing of learners and effective results of the teaching process prevailed as the most important objectives. Fulfilling the teaching plan also appeared as one of the most important objectives of the teaching process for four teachers. Interestingly, none of the respondents mentioned reaching communicative competence in the foreign language in any of their answers. 
Considering the teaching process itself, namely integrating specific aspects of communicative competence into lessons, we discovered that in accordance with the previous answers, teachers admitted integrating the components of linguistic competence into their lessons most frequently. They were asked about the elements of communicative competence indirectly. By being given examples on teaching individual components of language without explanations about which competence they belonged to, the teachers portrayed their lessons in detail and spoke about the procedural side of their teaching. On the basis of this, they portrayed how important they consider the individual competences, how frequently they include them into their teaching, and lastly, what their main aims in teaching are.

\begin{tabular}{|c|c|c|c|c|c|c|c|}
\hline \multicolumn{7}{|c|}{ Table 2: Teachingindividualcomponents of communicative competence } \\
\hline Competence & important & \multicolumn{2}{|c|}{ Frequency of inclusion } & Objectives \\
\cline { 2 - 8 } & Yes & no & +++ & ++ & + & - & $\begin{array}{c}\text { Solid foundations of language, } \\
\text { Lexical }\end{array}$ \\
15 & 0 & 15 & - & - & - & $\begin{array}{c}\text { development of listening and reading, good } \\
\text { performance during tests, } \\
\text { assistance in communication }\end{array}$ \\
\hline Grammatical & 11 & 4 & 11 & - & 4 & - & $\begin{array}{c}\text { Practicing communicative skills, practicing for } \\
\text { tests, assisting in communicative language use }\end{array}$ \\
\hline $\begin{array}{c}\text { Phonological } \\
\text { and orthoepic }\end{array}$ & 15 & - & 9 & 6 & - & - & $\begin{array}{c}\text { Understanding heard texts, } \\
\text { mastering speaking }\end{array}$ \\
\hline Orthographic & 15 & - & 8 & 5 & 2 & - & $\begin{array}{c}\text { Using language in written form, copying texts, } \\
\text { succeeding in tests }\end{array}$ \\
\hline Sociolinguistic & 15 & - & - & 8 & 4 & 3 & $\begin{array}{c}\text { Acquiring politeness phrases, } \\
\text { acquiring culture, } \\
\text { success in different situations }\end{array}$ \\
\hline Functional & 8 & 7 & 2 & - & 6 & 7 & Successful communication \\
\hline Discourse & 11 & 4 & 2 & - & 6 & 7 & $\begin{array}{c}\text { Coherent speech and writing, } \\
\text { success in communication }\end{array}$ \\
\hline Source: Author & & & & & \\
\hline
\end{tabular}

Lexical competence was found as the strongest component of linguistic competence. It was regarded as vital for all the respondents, and it was also declared as being integrated into the teaching very frequently. All the teachers unanimously answered that they deal with vocabulary and lexical items in every lesson and that they find it extremely important that their learners are provided a solid basis for language knowledge. They also explained that teaching vocabulary assists in the development of receptive skills as well as bettering performance on tests. Moreover, a few teachers regarded lexical competence as being important for students becoming successful communicators. Although for the importance and integration of grammatical competence at this level, not all the teachers had a unified opinion, they all admitted that grammar is also an essential part of language knowledge and is important to be dealt with from the very beginning of pupils' studies. According to their answers, grammar is beneficial at practicing all four communicative skills, is inevitable for succeeding in tests and examinations, and it also assists in the use of communicative language. Concerning phonological and orthoepic competence, it was discovered that the auditory aspect of language is important for all the 15 interviewed teachers. However, only five teachers considered both segmental and suprasegmental aspects of pronunciation as vital to be dealt with, whereas 10 of them claimed pronunciation of individual sounds and words only to be important. Although teachers include these competences into their teaching process very frequently, it is questionable whether pupils are provided good coverage of pronunciation by all the interviewed teachers. Lastly, all the teachers found orthographic competence as an important part of the teaching process. Some of them had difficulties estimating how often they integrate such teaching into their lessons, as it is frequently interconnected with other aspects of language and is dependent on many factors. By developing this competence, the teachers said their aim is to develop the ability to use language in written form for successful communication, develop the ability to copy texts, and succeed in tests.

The second-largest component of communicative competence - sociolinguistic competence, was regarded as vital to be developed by all the interviewees. The majority of teachers stated that they included it into their teaching at least once a week but never in every English class. Paradoxically, despite regarding it as vital, there were also teachers who admitted only including sociolinguistic 
teaching into their lesson once in a while or not including it at all. What is interesting, however, is that the respondents said that through such teaching, pupils should acquire politeness phrases and Anglophone culture, as well as learn how to succeed in various communicative situations. Despite these, the majority thought that involving linguistic components of FLE is more important for overall language knowledge.

The most alarming findings are depicted for pragmatic competence. For its two components, the standpoints of teachers were rather different in various areas, but the integration of them into the lessons revealed that both are rather neglected. Concerning functional competence, we discovered that teachers were split into two groups, almost equally divided into halves. The first group considered language functions as important to be dealt with. These teachers also said that they implement functions into the teaching very frequently. They consider functional competence as assisting in successful communication in discourse, in mastering productive skills, and in succeeding in classroom language. The second group consisted of 7 teachers who considered functions in language as not important and admitted to not including them in their teaching process more than once in a while. For discourse competence the interviews revealed that although the majority of teachers found such teaching as important and to be included in lessons, only a very small number of them include it into the teaching frequently enough and on a regular basis. Despite the fact that the teachers knew that by developing discourse competence pupils learn how to produce long, coherent stretches of speech and writing and enhance their success in communication, roughly half of them admitted neglecting it almost completely.

Similar to our findings, research conducted by Weerawong (2004), Gonzales-Pelaes (2008), and Wong (2010) also revealed that teachers find it difficult to define what communicative competence is. The linguistic aspect of language with mechanical memorization, vocabulary drills, and practice of receptive skills also dominated in other studies, whereas correct pronunciation was paid little or no attention to (Straksiene, 2011). A study conducted by Tavakoli and Hunter (2017) explains that, in reality, there is a great mismatch between theoretical research-based recommendations and the actual in-practice teaching in classes. There are several studies that show that different individual aspects of communicative competence are not covered sufficiently even in EFL textbooks used around the world (Lee, 2009; Wu, 2010; Yuen, 2011, Reid and Kovacikova, 2017; Paulikova, 2020). This makes us come to a conclusion that not only some of the components of communicative competence are neglected by teachers themselves, as frequently these components are not even covered properly in the teaching materials designed for schools. The requirement of both the national and international reference documents to develop communicative competence of pupils complexly (Council of Europe, 2001; Trim, 2001; SPU, 2019) therefore cannot be met completely. The teachers of our study have an incomplete view of what communicative competence is, which, according to our understanding, leads to incomplete integration of its components into the teaching process, as well.

\section{Conclusion}

The development of communicative competence generally is a very complex process, which is dependent on various factors. One of these factors, as the article portrayed, is teachers. The study was concerned with in-service teachers' standpoints towards this complex process at the primary level of education. We discovered that teachers have misconceptions about what communicative competence is. They refer to it as consisting of a sociolinguistic aspect, a grammatical aspect, and the ability to speak. They admit putting excessive effort into developing lexical, grammatical, and orthographic competence as opposed to phonological and orthoepic competence (which, although found vital to be developed, was admitted to being dealt with only partially). Regarding sociolinguistic competence, the teachers consider it important to be developed, but only approximately half of them admit to including it in their lessons frequently enough. Lastly, concerning pragmatic competence, approximately only half of the teachers consider functional competence to be important, but almost all do so for discourse competence. According to their answers, however, only approximately half of them involve these two competences in their teaching process frequently enough to provide a balanced development of pragmatic competence. According to this, we can state that teachers tend to integrate the components of linguistic competence into their teaching process most frequently, whereas sociolinguistic and pragmatic components of communicative competence are either not considered important or not integrated into the teaching process frequently enough and on a regular basis. 


\section{Acknowledgments}

The paper includes research results gained as a part of the project UGA V/8/2021 Vyučovanie a rozvoj komunikačnej kompetenciev anglickom jazyku na praktickej rovine.

\section{References}

Carter, R.,\&Nunan, D. (2001).The Cambridge Guide to Teaching English to speakers of other languages. 1st ed. New York: Cambridge University Press.

Cohen, L., Manion, L., \& Morrison, K. (2007). Research methods in education (6th ed.). Routledge/Taylor \& Francis Group. Council of Europe. (2001). The Common European Framework of Reference for Languages: Learning, Teaching and Assessment. Cambridge, U.K: Press Syndicate of the University of Cambridge.

Edwards, R., Holland, J. (2013). What is qualitative interviewing?. Bloomsbury Academic. pp. 2-3. ISBN 9781849668095.

Gómez-Rodríguez, L. F. (2010). English Textbooks for Teaching and Learning English as a Foreign Language: Do They Really Help to Develop Communicative Competence?.Educación y Educadores, 13(3), 327-346. Retrieved March 24, 2021, from http://www.scielo.org.co/scielo.php?script=sci_arttext\&pid=S0123-12942010000300002\&lng=en\&tlng=en.

González Peláez, M. E. (2008). English Teachers' Beliefs about Communicative Competence and their relationship with their Classroom Practices. Profile Issues in Teachers` Professional Development, (10), 75-90. Retrieved March 24, 2021, from http://www.scielo.org.co/scielo.php?script=sci_arttext\&pid=S1657-07902008000200005\&lng=en\&tlng=en.

Harmer, J. (2012). Essential Teacher Knowledge: Core Concepts in English Language Teaching. Harlow, England: Pearson Education Ltd.

KingRice, J. (2003).Teacher Quality: Understanding the Effectiveness of Teacher Attributes. Michigan: Economic Policy Institute

Kováčiková, E.,\&Veselá, K. G. (2016). Základydidaktikycudzíchjazykov [Basics of foreign language didactics]. Nitra: UKF Lee, I. (2009). Situated globalization and racism: An analysis of Korean high school EFL textbooks. In: Language \& Literacy, 11(1), 1-14.

Paulíková, K. (2019). Historical Outline on Teaching English as a foreign Language with Regards to Communicative Competence and its Importance within Slovak Primary Education. Jazykovedné, literárnovedné a didaktickékolokvium L3 :zborníkvedeckýchprác a vedeckýchštúdií. Bratislava: Z-F Lingua, 100-113.

Paulíková, K. (2020). Communicative Competence in Primary English Textbooks - a Content Analysis. Ad Alta: Journal of Interdisciplinary Research. 10 (1), 214-220. doi:10.33543/1001

Reid, E.,\&Kováčiková, E. (2017). How to choose the right English textbook? Problemyvczesnejedukacji/Issues in early education, 1 (36), 2017. 87 - 111.

Romaine, S. (2007). Preserving Endangered Languages. Language and Linguistic compass, 115- 131.

Savignon, S. J. (1972). Communicative Competence: An Experiment in Foreign-Language Teaching. Language and the Teacher. Applied Linguistics, Vol. 12

Szell, T. (2013). Factors Determining Student Achievement. In: Hungarian Educational Research Journal 2013, Vol. 3(3), $55-66$

SPU (2011). Inovovanýštátnyvzdelávací program pre 1.stupeň základnej školy - anglickýjazyk[Innovated national educational program for primary level - English language]. Retrieved from:

http://www.statpedu.sk/files/articles/dokumenty/inovovany-statny-vzdelavaci-program/aj_pv_2014.pdf

Straksiene, G. (2011). Characteristics of the Development of Junior Pupils' Communicative Competence at Primary School. In: TILTAI, 2011, 1, $123-138$

Tandlichová, E. (2008). Angličtina pre jazykovéškoly a kurzy 1[English for language schools and courses 1]. Ottovonakladatelstvo, s.r.o.

Tavakoli, P., \& Hunter, A.M. (2018).Is fluency being 'neglected' in the classroom? Teacher understanding of fluency and related classroom practices. Language Teaching Research, 22(3), 330-349.

Trim, J. L.M. (2001). Breakthrough.Unpublished manuscript. Retrieved from: http://www.englishprofile.org/928uncategorised/120-breakthrough

Ur, P. (1996). A course in language teaching.Cambridge University Press.

Weerawong, A. (2004). Communicative Language Teaching in Practice? A Study of Four Post-Graduate Student Teachers in Thailand (Doctoral dissertation). The National University of Singapore.

Wong, C. Y. (2010). Second Language Teachers' Perception and Implementation of Communicative Language Teaching. (Doctoral dissertation). Texas Tech University, Lubbock, Texas.

Wu, J. (2010). A content analysis of the cultural content in the EFL textbooks. Canadian Social Science, 6(5), 137-144.

Yuen, K. M. (2011). The representation of foreign cultures in English textbooks. ELT Journal, 65(4), 458-466. https://doi.org/ 10.1093/elt/ccq089 